\title{
Business Process Improvements on National E-KTP Retail Equipment Sales Using Business Model Canvas
}

\author{
Ovie Isnanda Irsa \\ Industrial Engineering Department, Master Program \\ Telkom University \\ Bandung, Indonesia \\ ovieisnandairsa@student.telkomuniversity.ac.id
}

Agus Achmad Suhendra

Industrial Engineering Department, Master Program

Telkom University

Bandung, Indonesia

agus@telkomuniversity.ac.id

DOI: 10.31364/SCIRJ/v8.i12.2020.P1220827

http://dx.doi.org/10.31364/SCIRJ/v8.i12.2020.P1220827

\begin{abstract}
PT XYZ is a State-Owned Enterprise (BUMN) which has several business units, one of them is engaged in Information and Communication Technology (ICT). PT XYZ is one of the largest distributors of E-KTP equipment in Indonesia which has a market share of 60\%. In 2019 there were several problems that occurred in the retail business elements of the E-KTP equipment at PT XYZ, namely the customer relationship element, channels element, revenue streams element and key resources element. The existence of the problems with the four of business elements resulted in the business model being less effective, so it was necessary to carry out a process of improvements in the business model. Through the Business Model Canvas method, a SWOT Analysis is carried out on four main aspects, namely value proposition, infrastructure, cost and revenue, and also customer relationship. Then the strategy design is also carried out using an analysis of the strengths, weakness, threats and opportunities based on experienced at PT XYZ. The selection of strategic priority was carried out by using Analytical Hierarchy Process (AHP) method which was carried out to 3 experts who were directly in contact with business process at PT XYZ. The output of this research are in the form of the proposed Business Model Canvas to be mapped on 9 buildings blocks namely the Customer Segment, Value Proposition, Channels, Customer Relationship, Revenue Streams, Key Activities, Key Partnership, Key Resources and Cost Structure.
\end{abstract}

Key Words: Business Model Canvas, Analysis SWOT, Analytical Hierarchy Process (AHP)

\section{INTRODUCTION}

PT XYZ is one of the largest distributors in the sale of E-KTP equipment in Indonesia which has a market share of $60 \%$. The equipment of E-KTP that offered by PT XYZ are in the form of printers, ribbons, films, cleaning kits, smart card readers, contact java cads, magic card printers and magic card ribbons. The target market for selling the equipment of E-KTP is local governments in Indonesia. However, in practice, the amount of PT XYZ revenue streams in the sale of the equipment of E-KTP decreased from 2019 to 2019, from IDR. 114.873.765.527 to IDR. 109.370.196.196. Based on information from PT XYZ's internal data for 2020, the number of PT XYZ resellers also decreased from 2018 to 2019. The percentage of reseller churn rates from 2019 to 2019 decreased by 12,50\%. Even though PT XYZ is a relatively large company, the website owned by PT XYZ only focuses on product knowledge, PT XYZ does not provide a platform for customers to express complaints so that customers use e-mail to submit their complaint. In 2019 the percentage of complaint emails that have not been read is $96 \%$, this indicates a problem with the customer relationship element in PT XYZ. Problems also occur in the key resources element at PT XYZ. Based on internal data from PT XYZ, the percentage of resellers who complained about the late issuance of invoices in June, July and August 2020 was $86 \%, 82 \%$ and $84 \%$, respectively. Because of there are problems in 4 business elements at PT XYZ, namely the elements of customer relationship, channels, revenue streams and key resources, making the business model so that the business model at PT XYZ becomes less effective. This is the reason why PT XYZ's business model needs to be improved.

The Business Model Canvas (BMC) is a conceptual design of a business model that represents the strategy and business processes in the organization (Osterwalder \& Pigneur, 2012).

www.scirj.org

(C) 2020, Scientific Research Journal

http://dx.doi.org/10.31364/SCIRJ/v8.i12.2020.P1220827

This publication is licensed under Creative Commons Attribution CC BY. 
The Business Model Canvas (BMC) is one way to make it easier for business actors to find the strategy to run their business. In the Business Model Canvas (BMC), there are nine elements that affect a business. The nine elements are Customer Segment, Value Proposition, Customer Relationship, Channels, Key Partners, Key Activities, Key Resources, Revenue Streams and Cost Structure.

The purpose of this research is to find out :

1. Identifying the existing business model for the retail process of the equipment of E-KTP at PT XYZ

2. Identifying the condition of internal factors for the retail process of the equipment of E-KTP at PT XYZ

3. Identifying the condition of external factors for the retail process of the equipment of E-KTP at PT XYZ

4. Designing the right business model for the retail process of the equipment of E-KTP at PT XYZ

5. Creating the business strategy that is appropriate and recommended as a strategy for developing the retail process of the equipment of E-KTP at PT XYZ

\section{LITERATURE REVIEW}

\section{Business Model}

A business model describes thinking about how organizations create, deliver, and capture value (Osterwalder \& Pigneur, 2012). A business model is a method used by companies to make money in the business environment in which the company operates (Hunger \& Wheelen, 2012). The benefits of having a business model are (Hunger \& Wheelen, 2012) :

1. The business model makes it easy for planners and decision makers in the company to see the logical relationship between the natural components of the business, so that value for consumers and value for the company can be generated.

2. The business model can be used to help test the consistency of the relationship between its components.

3. Business models can be used to help test the market and the assumptions used when developing a business.

4. A business model can be used to show how radical a change is and its consequences.

\section{SWOT Analysis}

SWOT Analysis is a way to systematically identify various factors to formulate a company strategy. This analysis is based on logic that maximizes strengths and opportunities, but at the same time minimize weakness and threats (Rangkuti, 2014). The strategic decision-making process is always related to the development of the company's mission, objectives, strategies and policies. Thus the strategic planner must analyze the company's strategic factors (strengths, weakness, opportunities, threats) in the current conditions (Rangkuti, 2014). Strengths and weakness are internal (controllable) factors that support and hinder organizations from achieving their respective missions. Whereas opportunities and threats are external (uncontrollable) factors that enable and disable organizations from achieving their mission (Dyson, 2004). Research shows that company performance can be determined by a combination of internal and external factors. These two factors must be considered in a SWOT analysis. SWOT stands for internal strengths and weakness environment of Opportunities and threats faced. SWOT analysis compares internal environmental factors ti the external environment (Rangkuti, 2014).

\section{Qualitative Analysis and Quantitative Analysis}

Qualitative analysis is an analysis that describes descriptive data based on real conditions, field notes during observation, and others. Qualitative analysis is carried out to determine what factors affect the company, both in terms of strength, weakness, opportunity and strength.

Overall evaluation of strengths, weakness, opportunities and threats is also SWOT Analysis (Kotler \& Keller, 2007)

\section{Strengths}

That is the strength possessed by the company compared to their companies.

\section{Weakness}

That is the problems faced by the company compared to other companies, so this is a minus/weakness for the company.

\section{Opportunity}

That is an opportunity where the company can carry out operations in dealing with it to turn this opportunity into an advantage.

\section{Threat}

It is a danger that is usually due to unfavorable developments, which will have impacts such as reduced profits and sales if no action is taken to survive.

Quantitative analysis is an analysis that uses quantitative data or statistical numbers or quantifiable codes. Quantitative analysis is 
obtained from the formulation of a qualitative analysis that has been given a score or value so that researches can calculate and find out which position the company being researched is in.

SWOT analysis is carried out through a series of calculations known as the calculation of IFAS (Internal Factor Analysis Strategy) and EFAS (External factor Analysis Strategy).

\section{Internal Factor Analysis Strategy (IFAS)}

This is the steps for calculating IFAS (Rangkuti, 2014)

- Enter the strengths and weakness in the IFAS table column 1. Compile 5 strength factors and 5 weakness factors.

- Weight each strategic factor in column 2, on a scale of 0.0 (not important) to 1.0 (very important). All weights are mentioned as not exceeding the total score of 1.00 . these factors are weighted based on strategic influence

- Give a rating in column 3 for each factor with a scale ranging from 10 (very strong) to 1 (weak), based on the influence of the analyzed variables. Positive variables included in the strength category) are scored $6-10$ by comparing them to the average of the main competitors. While the negative variable is the opposite if the weakness is very large (compared to the advantage competitor) the value is 1 , whereas if the weakness value is low / below the average competitors-the value is 5 .

- Multiply the weight by the value (rating) to get the weighting factors in column 4 . The result is a weighted score for each factor, which varies from 4.0 (prominent) to 1.0 (weak).

- Added up the weighted scores (in column 4) to get the total factor weight scores analyzed. This total value shows how the variable reacts to its internal strategic factor.

The following is a table in the calculating of IFAS (Internal Factor Analysis Strategy)

Table 1 Internal Factor Analysis Strategy (IFAS)

\begin{tabular}{|l|l|l|l|l|}
\hline No & Strength & Weight & Rating & $\begin{array}{l}\text { Weighting } \\
\text { Factor }\end{array}$ \\
\hline 1 & & & & \\
\hline$\ldots$ & & & & \\
\hline 5 & \multicolumn{5}{|c|}{ The Strength Value } & & \\
\hline No & Weakness & Weight & Rating & $\begin{array}{l}\text { Weighting } \\
\text { Factor }\end{array}$ \\
\hline 1 & & & & \\
\hline$\ldots$ & & & & \\
\hline
\end{tabular}

\begin{tabular}{|l|c|c|c|}
\hline 5 & & & \\
\hline \multicolumn{3}{|c|}{ The Weakness Value } & $\mathrm{b}$ \\
\hline \multicolumn{3}{|c|}{ Difference = Strength - Weakness } & $\mathrm{x}=\mathrm{a}-\mathrm{b}$ \\
\hline
\end{tabular}

2. External Factor Analysis Strategy (EFAS)

This is the steps for calculating IFAS (Rangkuti, 2014)

- Enter the opportunity and threat in the EFAS table column 1. Compile 5 strength factors and 5 weakness factors.

- Weight each strategic factor in column 2, on a scale of 0.0 (not important) to 1.0 (very important). All weights are mentioned as not exceeding the total score of 1.00 . these factors are weighted based on strategic influence

- Give a rating in column 3 for each factor with a scale ranging from 10 (very strong) to 1 (weak), based on the influence of the analyzed variables. Positive variables included in the strength category) are scored $6-10$ by comparing them to the average of the main competitors. While the negative variable is the opposite if the weakness is very large (compared to the advantage competitor) the value is 1 , whereas if the weakness value is low / below the average competitors-the value is 5 .

- Multiply the weight by the value (rating) to get the weighting factors in column 4 . The result is a weighted score for each factor, which varies from 4.0 (prominent) to 1.0 (weak).

- $\quad$ Added up the weighted scores (in column 4) to get the total factor weight scores analyzed. This total value shows how the variable reacts to its internal strategic factor.

The following is a table in the calculating of EFAS (External Factor Analysis Strategy)

Table 2 External Factor Analysis Strategy (EFAS)

\begin{tabular}{|c|c|c|c|c|}
\hline No & Opportunity & Weight & Rating & $\begin{array}{l}\text { Weighting } \\
\text { Factor }\end{array}$ \\
\hline \multicolumn{5}{|l|}{1} \\
\hline \multicolumn{5}{|l|}{$\ldots$} \\
\hline \multicolumn{5}{|l|}{5} \\
\hline \multicolumn{4}{|c|}{ The Strength Value } & $\mathrm{c}$ \\
\hline No & Threats & Weight & Rating & $\begin{array}{l}\text { Weighting } \\
\text { Factor }\end{array}$ \\
\hline \multicolumn{5}{|l|}{1} \\
\hline$\ldots$ & & & & \\
\hline \multicolumn{5}{|l|}{5} \\
\hline \multicolumn{4}{|c|}{ The Weakness Value } & $\mathrm{d}$ \\
\hline \multicolumn{4}{|c|}{ Difference = Opportunity - Threats } & $y=c-d$ \\
\hline
\end{tabular}




\section{SWOT Matrix}

The SWOT matrix is used t develop an organization or company strategy that clearly describes the opportunities and threats facing the organization or company so that it can be adjusted to the strengths and weaknesses of the organization or company. This matrix generates four possible alternative strategies, namely S-O strategy, W-O strategy, S-T strategy and W-T strategy.

\section{S-O Strategy}

This strategy utilizes all strengths to seize an take advantage of existing opportunities.

\section{S-T Strategy}

This strategy uses the strength of the company to overcome threats

\section{W-O Strategy}

This strategy takes advantage of existing opportunities by minimizing existing weakness

\section{W-T Strategy}

This strategy is based on activities that are diffensive and try to minimize existing weakness and avoid threats.

\section{IE Matrix}

IE Matrix places the various divisions of an organization in nine cells (David, 2009). The IE matrix is based on two keys dimensions, namely the number of IFE values weighted on the $x$ axis and the number of EFE values weighted on the y-axis. On the $\mathrm{x}$-axis of the IE matrix, the total IFE score of $1.0-1.99$ indicates a weak internal position, a score of $2.0-2.99$ indicates an average, a score of 3.0 to 4 indicates a strong internal position. On the y-axis, an EFE total weighted score of 1.0 to 1.99 indicates moderate, and a score of 3.0 to 4.0 indicates high.

The IE Matrix can be divided into three main strategic implication

\section{Growth Strategy}

Cells I, II, or IV are referred to as growth and development strategies, the right strategies are intensive strategies (market penetration, market development, and product development) or integrative strategies (backward integration, forward integration and horizontal integration).

\section{Stability Strategy}

Cell III, V or VII are referred to as defense and maintenance strategies. Market penetration and product development are strategies that are often used when the company is in this position.

\section{Retenchment Strategy}

Cells VI, VIII, or IX are called the harvest or divestment strategy.

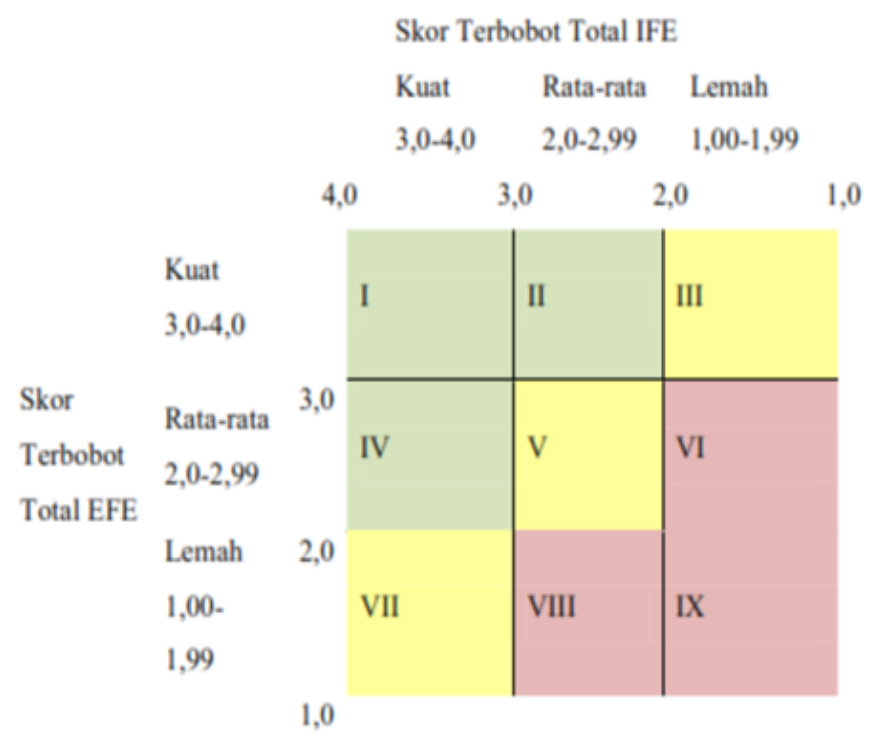

Figure 1 IE Matrix

\section{Business Model Canvas (BMC)}

The Business Model Canvas (BMC) is a strategic tool used to describe a business model and illustrate the rationale for how organizations create, deliver and capture the value (Osterwalder \& Pigneur, 2012). This business model was first introduced by Alexander Osterwalder in his book, Business Model Generation. In his book, Alexander Osterwalder tries to explain a simple framework for presenting the important elements contained in a business model.

The Business Model Canvas (BMC) is an effective method because the analysis used is able to explain thoroughly both in terms of marketing, human resources, finance, to the value or product offered, so that the company can determine the direction of moving for the company and know the competitive advantages that is in the business he is running (Osterwalder \& Pigneur, 2012).

www.sciri.org 
The business model canvas transforms a complex business model concept into a simple business model that is divided into 9 elements.

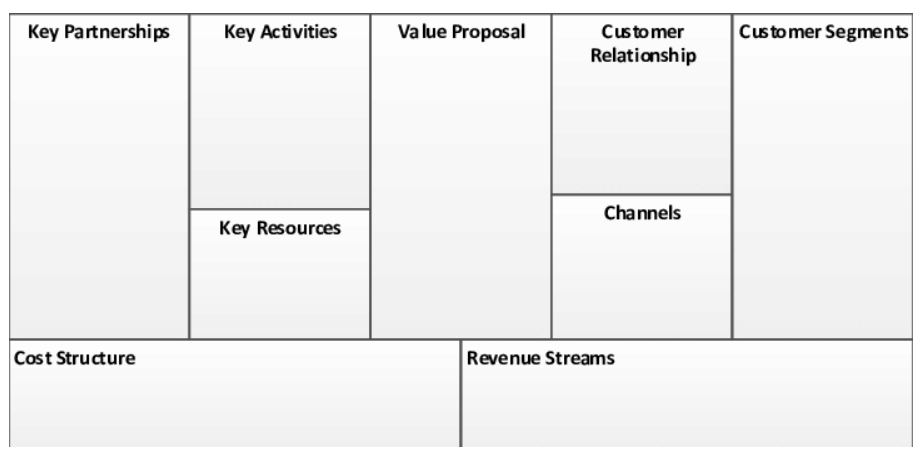

Figure 2 Business Model Canvas

\section{Analytical Hierarchy Process (AHP)}

Analytical hierarchy process is a multi criteria measurement that helps to overcome problems in making decisions on quite complex problems. AHP is carried out by structuring problems, identifying decision-making factors, measuring the importance of factors, a model to help companies in making decisions (Saaty, 2008).

The AHP method is a method that utilizes the human ability to identify and communicate what they observe and feel. With the hierarchy model, it is hoped that it can make it easier for humans to identify situations in detail from a complex problem. The hierarchy model has three major parts, namely goals, objectives and alternatives.

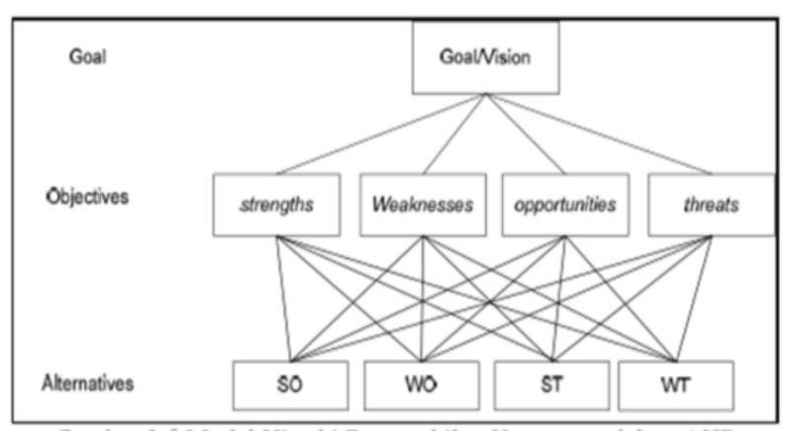

Figure 3 Hierarchy Model

\section{METHODOLOGY}

\section{Characteristic of the Study}

This research is structured systematically in order to produce output in the form of appropriate planning for solving the problems being studied. This research uses a case study taken at PT XYZ where PT XYZ is one of the state-owned companies in Indonesia. PT XYZ has several business lines, one of which is engaged in Information and Communication Technology (ICT Business). One of the products marketed in this ICT business line is the equipment of E-KTP which is the object of research in this study.

This research uses qualitative and quantitative methods. The qualitative methods used are the SWOT Analysis method and the Business Model Canvas, while the quantitative method used is the Analytical Hierarchy Process (AHP) method.

The data collection process in this study was carried out by brainstorming and direct interviews with employees at PT XYZ to see the internal factors that exist in this company. Questionnaires were also distributes to employees at PT XYZ for AHP Analysis in order to obtain primary data. Meanwhile, secondary data is obtained from books and related journals to help understand the implementation of the methods used.

\section{DISCUSSION}

\section{Business Model Canvas Existing}




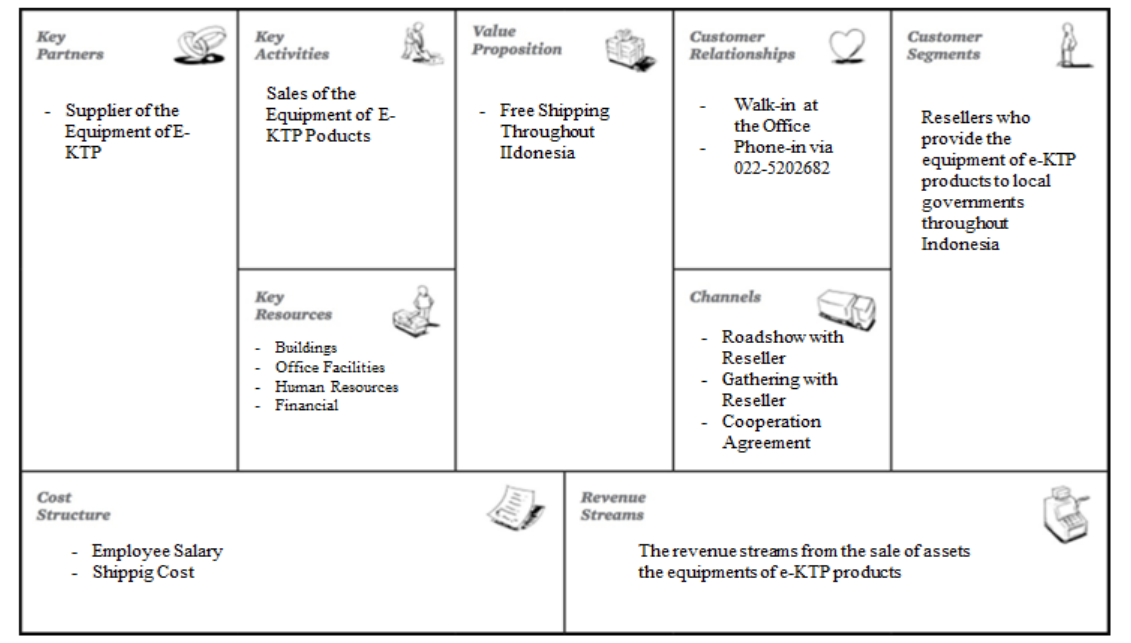

Figure 4 Business Model Canvas Existing

a. Customer Segment Existing

Table 3 Customer Segment Existing

\begin{tabular}{|l|lr|l|}
\hline No & \multicolumn{3}{|c|}{ Customer Segment } \\
\hline & Segment & Problem \\
\hline 1 & $\begin{array}{l}\text { Companies throughout } \\
\text { Indonesia that sell the } \\
\text { equipment of E-KTP } \\
\text { products to local } \\
\text { governments }\end{array}$ & $\begin{array}{l}\text { The classification is based } \\
\text { on resellers who shop at } \\
\text { PT XYZ }\end{array}$ \\
\hline 2 & $\begin{array}{l}\text { Middle and Upper } \\
\text { Companies }\end{array}$ & $\begin{array}{l}\text { This classification is based } \\
\text { on the company that buys } \\
\text { the products is classified } \\
\text { as a reseller, so there is a } \\
\text { minimum purchase and } \\
\text { they will sell again to the } \\
\text { end user }\end{array}$ \\
\hline
\end{tabular}

b. Value Proposition Existing

Table 4 Value Proposition Existing

\section{Value Proposition}

Free shipping throughout Indonesia

c. Channels Existing

As one of the largest distributors in Indonesia, PT XYZ provides free shipping facilities for resellers throughout Indonesia without a minimum purchase
Table 5 Channels Existing

\begin{tabular}{|c|c|}
\hline \multicolumn{2}{|r|}{ Channels } \\
\hline Roadshow with reseller & $\begin{array}{l}\text { PT XYZ regularly } \\
\text { roadshows to potential resellers } \\
\text { who will participate in the } \\
\text { procurement process in the } \\
\text { Regional Government. }\end{array}$ \\
\hline Gathering with reseller & $\begin{array}{l}\text { PT XYZ regularly holds } \\
\text { gatherings with resellers in order } \\
\text { to establish communication } \\
\text { between each other }\end{array}$ \\
\hline Cooperation Agreement & $\begin{array}{l}\text { Reseller who routinely produce the } \\
\text { equipment of E-KTP products in } \\
\text { large quantities to PT XYZ each } \\
\text { year will be given special } \\
\text { facilities, namely Cooperation } \\
\text { Agreement which promises the } \\
\text { reseller to make a 30-day } \\
\text { backward payment transaction } \\
\text { since the purchase order to PT } \\
\text { XYZ, so that the reseller can have } \\
\text { time to process the payment. }\end{array}$ \\
\hline
\end{tabular}

d. Customer Relationship Existing

Table 6 Customer Relationship Existing

\section{Customer Relationship}

\begin{tabular}{|lll|l|}
\hline $\begin{array}{l}\text { Walk-in affice } \\
\text { Ot the }\end{array}$ & $\begin{array}{l}\text { Reseller can go directly to the office to } \\
\text { place an order for the equipment of E- } \\
\text { KTP products. PT XYZ always tries to } \\
\text { improve service in the office by } \\
\text { creating a comfortable waiting room } \\
\text { and friendly service. }\end{array}$ \\
\hline $\begin{array}{l}\text { Phone-in via 022- } \\
\text { 520XXX }\end{array}$ & $\begin{array}{l}\text { Resellers can contact PT XYZ via } \\
\text { telephone, PT XYZ is trying to } \\
\text { increase the number of Account }\end{array}$ \\
\hline
\end{tabular}

www.scirj.org

(C) 2020, Scientific Research Journal

http://dx.doi.org/10.31364/SCIRJ/v8.i12.2020.P1220827

This publication is licensed under Creative Commons Attribution CC BY. 


\begin{tabular}{|l|l|}
\hline & $\begin{array}{l}\text { Executive and Admins so that the } \\
\text { reseller queue is not too long }\end{array}$ \\
\hline
\end{tabular}

e. Revenue Streams

Table 7 Revenue Streams Existing

\begin{tabular}{|c|c|}
\hline \multicolumn{2}{|c|}{ Revenue Streams } \\
\hline Sales & Revenue from PT XYZ in the E- \\
& KTP retail is sale of the \\
& equipment of E-KTP products \\
& namely sales of printers, ribbon \\
& films, cleaning kits, smart cards, \\
& contact java cards, magic card \\
& printers and magic card ribbons. \\
\hline
\end{tabular}

f. Key Resources

Table 8 Key Resources Existing

\begin{tabular}{|l|l|}
\hline \multicolumn{2}{|l|}{ Key Resources } \\
\hline Buildings & $\begin{array}{l}\text { Buildings is one of the important assets } \\
\text { of the company, without a building it } \\
\text { will be difficult for the company stand } \\
\text { because it does not have an office to } \\
\text { carry out the company activities }\end{array}$ \\
\hline Office Facilities & $\begin{array}{l}\text { Not only buildings, office facilities are } \\
\text { also company assets that assist } \\
\text { employees in conducting business } \\
\text { operations. }\end{array}$ \\
\hline Human Resources & $\begin{array}{l}\text { Human resources are the main assets of } \\
\text { the company, without the competent of } \\
\text { human resources its possible for a } \\
\text { company to continue to exist }\end{array}$ \\
\hline Financial & $\begin{array}{l}\text { Financial is also an important asset, } \\
\text { without a good financial services, it is } \\
\text { impossible for the company to continue } \\
\text { to carry out the business operations. }\end{array}$ \\
\hline
\end{tabular}

g. Key Activities

Table 9 Key Activities Existing

\begin{tabular}{|l|l|}
\hline \multicolumn{2}{|c|}{ Key Activities } \\
\hline Purchase & $\begin{array}{l}\text { The process of purchasing goods is } \\
\text { carried out by making a Purchase } \\
\text { Order (PO) which is a document that } \\
\text { contains a request for stock needs and } \\
\text { it is sent from PT XYZ to the supplier }\end{array}$ \\
\hline Sales & $\begin{array}{l}\text { The process of selling products is } \\
\text { carried out to the resellers who have } \\
\text { made Purchase Order (PO) to PT XYZ }\end{array}$ \\
\hline
\end{tabular}

\section{Supplier}

42

\begin{tabular}{|c|c|}
\hline Supplier & $\begin{array}{l}\text { Supplier is the sole agent that } \\
\text { provides e-KTP equipment products } \\
\text { in Indonesia. PT XYZ collaborates } \\
\text { with the suppliers to produce stock } \\
\text { of the equipment of E-KTP product } \\
\text { at PT XYZ. The cooperation was } \\
\text { validated by signing a contract } \\
\text { between supplier and the } \\
\text { Operational Director of PT XYZ. }\end{array}$ \\
\hline
\end{tabular}

i. Cost Structure Existing

Table 11 Cost Structure

\begin{tabular}{|l|l|}
\hline \multicolumn{2}{|c|}{ Cost Structure } \\
\hline Shipping Cost & $\begin{array}{l}\text { PT XYZ provides free shipping } \\
\text { facilities to all resellers throughout } \\
\text { Indonesia, so PT XYZ must bear the } \\
\text { shipping cost }\end{array}$ \\
\hline Employee Salary & $\begin{array}{l}\text { PT XYZ is obliged to pay for its } \\
\text { employee's salaries once a month }\end{array}$ \\
\hline
\end{tabular}

\section{SWOT Analysis of the Business Model Canvas Existing}

In the process of designing a new business model, data has been collected and analyzed using a SWOT analysis. SWOT analysis is useful for knowing the strengths, weakness, opportunity and threats in the business process existing. In this SWOT analysis, 4 aspects will be assessed, namely an assessment of the value proposition, an assessment of costs/revenues, an assessment of infrastructure and an assessment of customer relationships. The assessment was carried out using questionnaires using a likert scale to 3 sources from internal PT XYZ. The following is the recapitulation result of the questionnaire on the 4 aspects of the assessment.

Table 12 PT XYZ's Existing Business Model Interpretation Score

\begin{tabular}{|l|l|l|l|l|}
\hline \multicolumn{5}{|c|}{ PT XYZ's Existing Business Model Interpretation Score } \\
\hline & $\begin{array}{l}\text { Value } \\
\text { Propositio } \\
\mathrm{n}\end{array}$ & $\begin{array}{l}\text { Costs / } \\
\text { Revenues }\end{array}$ & $\begin{array}{l}\text { Infrastruct } \\
\text { ure }\end{array}$ & $\begin{array}{l}\text { Customer } \\
\text { Relationship }\end{array}$ \\
\hline $\begin{array}{l}\text { Strength } \\
\text { and } \\
\begin{array}{l}\text { Weaknes } \\
\text { s }\end{array}\end{array}$ & 11.75 & 9.75 & 9.3 & 8.7 \\
\hline $\begin{array}{l}\text { Opportu } \\
\text { nity }\end{array}$ & 10 & 9.6 & 9.9 & 7.7 \\
\hline Threats & 7 & 8.4 & 7.7 & 9.2 \\
\hline
\end{tabular}

h. Key Partnership

Table 10 Key Partnership Existing

Key Partnership

www.scirj.org

(C) 2020, Scientific Research Journal

http://dx.doi.org/10.31364/SCIRJ/v8.112.2020.P1220827

This publication is licensed under Creative Commons Attribution CC BY. 
Table 13 Likert Scale

\begin{tabular}{|l|l|l|}
\hline Category & $\begin{array}{l}\text { Interval Continuum } \\
\text { Line Spacing }\end{array}$ & Color \\
\hline Very Low & $3-5,4$ & \\
\hline Low & $>5,4-7,8$ & \\
\hline Medium & $>7,8-10,2$ & \\
\hline High & $>10,2-12,6$ & \\
\hline Very High & $>12,6-15$ & \\
\hline
\end{tabular}

Based on the interpretation score data from the results of the SWOT Analysis on the existing business model of PT XYZ, it can be seen that the value proposition of PT XYZ has a high category of strength, namely 11.75 . this indicates that the value proposition offered by PT XYZ is in line with customer needs, the value proposition offered has a strong network impact, there is a strong synergy between the products and services of PT XYZ and PT XYZ's customers are very satisfied. For the value proposition aspect, PT XYZ has sufficient opportunity, which is equal to 10 , while the threat that occurs in the value proposition aspect is low, namely 7 . The existence of sufficient value opportunities means that PT $\mathrm{XYZ}$ is able to meet additional customer needs, can complement or expand its value proposition, and can better integrate products or services the threat that occurs in the value proposition is also classified as low, this threat can be in the form of peasants who have substituted products for products sold by PT XYZ and threaten to offer a better price or value than PT XYZ.

In the aspect of cost and income, for strength it has a value of 9.75 which is included in the sufficient category, so it needs to be increased again through the opportunities it has. PT XYZ has an opportunity value of 9.6 in a sufficient category. The opportunity is that PT XYZ is able to replace revenue from one transaction with recurring income and PT XYZ has other revenue streams that can be added or created. As for the threat, at the expanse of costs and revenues of PT XYZ, there is a considerable threat, this threat could be in the form of a margin of PT XYZ being threatened by competitors or presence of the technology, however this can be minimized by implementing the opportunities it has.

In the infrastructure aspect, PT XYZ has sufficient strength of 9.3 , while the opportunities in the infrastructure aspect it has a value of 9.9 and is in the sufficient category. PT XYZ can implement existing opportunities to increase its strengths, these opportunities are by increasing efficiency in general, utilizing information technology to support PT XYZ to increase efficiency, utilizing partner channels to help PT XYZ reach the better customers, utilizing partners to complement the value proposition of PT XYZ and collaborating more strongly with partners to help focus on core business. For threats that occur in the infrastructure aspect, it is classified as low because it has a value of 7.7. The threat that can occur is that PT XYZ has key activities that can be disrupted, in which case PT XYZ must be able to minimize this threat by exploiting existing opportunities.

In the aspects of customer relations, PT XY has sufficient strength with a value of 8.7. however, in terms of opportunities for PT XYZ to have a value of 7.7 which is classified as low, this is because PT XYZ has not recognized and released unprofitable customers, PT XYZ has also not automated some relationships so that PT XYZ has not been able to improve efficiency of channels. In the aspect of customer relations, PT XYZ has a threat with a value of 9.2 which is quite large. These threats include customer relationships that are in danger of the deteriorating, competitors are threating the channel from PT XYZ and the high likelihood of customer crossing over. Because of this, PT XYZ needs to take advantage of the existing opportunities so that the threats they fear do not occur.

\section{Internal \& External Factor Analysis}

After conducting brainstorming based on direct observation of PT XYZ to identify internal factors (strengths and weakness) shown in table 14, and also conducting interviews with PT $\mathrm{XYZ}$ to identify external factors (opportunity and threat) as in table 15 , then weighting is carried out through distribution questionnaire to the company to find out preferences among all the factors shown in table 16 for IFAS weighting and table 17 for weighting EFAS.

Table 14 Strength and Weakness Factor

\begin{tabular}{|l|l|c|}
\hline No & \multicolumn{1}{|c|}{ Strength } & Code \\
\hline 1 & PT XYZ sells quality products & S1 \\
\hline 2 & $\begin{array}{l}\text { PT XYZ provides free shipping discounts } \\
\text { throughout Indonesia }\end{array}$ & S2 \\
\hline 3 & Human resources at PT XYZ are competent & S3 \\
\hline 4 & PT XYZ always delivers on time & S4 \\
\hline 5 & PT XYZ has responsible services to customers & S5 \\
\hline No & \multicolumn{1}{|c|}{ Weakness } & Code \\
\hline 1 & $\begin{array}{l}\text { The management at PT XYZ is not well } \\
\text { organized }\end{array}$ & W1 \\
\hline 2 & The technology at PT XYZ is still quite simple & W2 \\
\hline 3 & $\begin{array}{l}\text { Customers are difficult to find channels at PT } \\
\text { XYZ }\end{array}$ & W3 \\
\hline 4 & $\begin{array}{l}\text { Human resources productivity at PT XYZ is } \\
\text { still low }\end{array}$ & W4 \\
\hline 5 & $\begin{array}{l}\text { Standard Operating Procedures at PT XYZ are } \\
\text { less efficient }\end{array}$ & W5 \\
\hline
\end{tabular}

Table 15 Opportunity and Threats Factor

\begin{tabular}{|l|l|c|}
\hline No & \multicolumn{1}{|c|}{ Opportunity } & Code \\
\hline 1 & PT XYZ has the largest market in Indonesia & O1 \\
\hline 2 & PT XYZ has a strong brand & O2 \\
\hline 3 & Utilization of Information Technology can & O3 \\
\hline
\end{tabular}

www.scirj.org

(C) 2020, Scientific Research Journal

http://dx.doi.org/10.31364/SCIRJ/v8.i12.2020.P1220827

This publication is licensed under Creative Commons Attribution CC BY. 


\begin{tabular}{|l|l|c|}
\hline & increase efficiency in general & \\
\hline 4 & PT XYZ often has recurring income & O4 \\
\hline 5 & $\begin{array}{l}\text { There is a cooperation agreement between PT } \\
\text { XYZ and customers }\end{array}$ & O5 \\
\hline No & \multicolumn{1}{|c|}{ Threats } & Code \\
\hline 1 & $\begin{array}{l}\text { Competitors threaten to offer a better price or } \\
\text { value }\end{array}$ & T1 \\
\hline 2 & $\begin{array}{l}\text { PT XYZ's margins are threatened by } \\
\text { competitors or technology }\end{array}$ & T2 \\
\hline 3 & \multicolumn{1}{|c|}{$\begin{array}{l}\text { There are customer relationships that are in } \\
\text { danger of deteriorating }\end{array}$} & T4 \\
\hline 5 & PT XYZ is late in adopting technology & T5 \\
\hline
\end{tabular}

\begin{tabular}{|c|c|c|c|c|}
\hline & market in Indonesia & & & \\
\hline 2 & $\begin{array}{l}\text { PT XYZ has a strong } \\
\text { brand }\end{array}$ & 0.08 & 4.0 & 0.31 \\
\hline 3 & $\begin{array}{l}\text { Utilization of Information } \\
\text { Technology can increase } \\
\text { efficiency in general }\end{array}$ & 0.09 & 3.7 & 0.33 \\
\hline 4 & $\begin{array}{l}\text { PT XYZ often has } \\
\text { recurring income }\end{array}$ & 0.06 & 3.7 & 0.24 \\
\hline 5 & $\begin{array}{l}\text { There is a cooperation } \\
\text { agreement between PT } \\
\text { XYZ and customers }\end{array}$ & 0.09 & 4.0 & 0.36 \\
\hline \multicolumn{4}{|c|}{ Score } & 1.42 \\
\hline No & & Weight & Rating & Score \\
\hline 1 & $\begin{array}{l}\text { Competitors threaten to } \\
\text { offer a better price or } \\
\text { value }\end{array}$ & 0.17 & 1.7 & 0.28 \\
\hline 2 & $\begin{array}{l}\text { PT XYZ's margins are } \\
\text { threatened by competitors } \\
\text { or technology }\end{array}$ & 0.11 & 1.0 & 0.11 \\
\hline 3 & & 0.12 & 1.3 & 0.16 \\
\hline 4 & $\begin{array}{l}\text { There are customer } \\
\text { relationships that are in } \\
\text { danger of deteriorating }\end{array}$ & 0.09 & 1.7 & 0.15 \\
\hline 5 & $\begin{array}{l}\text { PT XYZ is late in } \\
\text { adopting technology }\end{array}$ & 0.14 & 1.0 & 0.14 \\
\hline \multicolumn{4}{|c|}{ Score } & 0.84 \\
\hline
\end{tabular}

Table 16 IFAS Calculations

\begin{tabular}{|c|c|c|c|c|}
\hline No & & Weight & Rating & Score \\
\hline 1 & $\begin{array}{l}\text { PT XYZ sells quality } \\
\text { products }\end{array}$ & 0.06 & 4.00 & 0.24 \\
\hline 2 & $\begin{array}{l}\text { PT XYZ provides free } \\
\text { shipping discounts } \\
\text { throughout Indonesia }\end{array}$ & 0.07 & 3.67 & 0.26 \\
\hline 3 & $\begin{array}{l}\text { Human resources at PT } \\
\text { XYZ are competent }\end{array}$ & 0.06 & 3.67 & 0.23 \\
\hline 4 & $\begin{array}{l}\text { PT XYZ always delivers } \\
\text { on time }\end{array}$ & 0.08 & 4.00 & 0.33 \\
\hline 5 & $\begin{array}{l}\text { PT XYZ has responsible } \\
\text { services to customers }\end{array}$ & 0.11 & 3.67 & 0.41 \\
\hline \multicolumn{4}{|c|}{ Score } & 1.48 \\
\hline No & & Weight & Rating & Score \\
\hline 1 & $\begin{array}{l}\text { The management at PT } \\
\mathrm{XYZ} \text { is not well } \\
\text { organized }\end{array}$ & 0.09 & 1.67 & 0.15 \\
\hline 2 & $\begin{array}{l}\text { The technology at PT } \\
\text { XYZ is still quite simple }\end{array}$ & 0.12 & 1.67 & 0.20 \\
\hline 3 & $\begin{array}{l}\text { Customers are difficult to } \\
\text { find channels at PT XYZ }\end{array}$ & 0.11 & 1.00 & 0.11 \\
\hline 4 & $\begin{array}{l}\text { Human resources } \\
\text { productivity at PT XYZ is } \\
\text { still low }\end{array}$ & 0.15 & 1.33 & 0.20 \\
\hline 5 & $\begin{array}{l}\text { Standard Operating } \\
\text { Procedures at PT XYZ are } \\
\text { less efficient }\end{array}$ & 0.14 & 1.33 & 0.18 \\
\hline \multicolumn{4}{|c|}{ Score } & 0.85 \\
\hline
\end{tabular}

\section{IE Matrix}

IE matrix is used to map the position of business units to make it easier to formulate appropriate alternative strategies. IE matrix is based on two main dimensions, namely internal factors and external factors.

To compile the IE matrix, the result obtained from the IFE matrix and EFE matrix are used. The total value of the IFE matrix is 2.32 while the total value of the EFE matrix is 2.26.these result position of PT XYZ in cell $\mathrm{V}$ as shown in the figure 5 on below.

These $\mathrm{V}$ cells are referred to as the defense and maintenance strategy. In this position PT XYZ is advised to carry out a market penetration strategy and product development.

Table 17 EFAS Calculations

\begin{tabular}{|l|l|l|l|l|}
\hline No & & Weight & Rating & Score \\
\hline 1 & PT XYZ has the largest & 0.05 & 3.7 & 0.19 \\
\hline
\end{tabular}

www.scirj.org

(C) 2020, Scientific Research Journal

http://dx.doi.org/10.31364/SCIRJ/v8.i12.2020.P1220827

This publication is licensed under Creative Commons Attribution CC BY. 


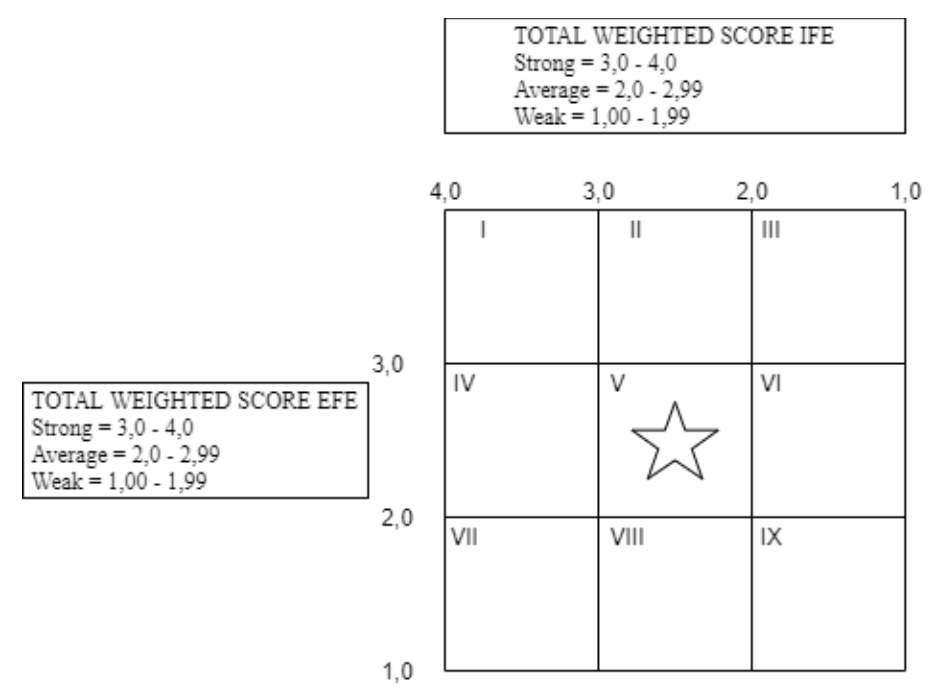

Figure 5 IE Matrix Calculations

\section{SWOT Matrix}

The SWOT matrix analysis represents concrete steps that should be taken by PT XYZ to maintain its business. This SWOT matrix analysis is based on the development of the IE Matrix. Analysis of the SWOT matrix produces several alternative strategies that will be suggested for PT XYZ.
The main strategies that can be suggested consist of 4 types, namely the SO, ST, WO, and WT strategies. This analysis uses data that has been obtained from the EFE and IFE matrixes. The summary of the analysis results can be seen in the Table 18.

Table 18 SWOT Matrix

\begin{tabular}{|c|c|c|}
\hline & Strength & Weakness \\
\hline & $\begin{array}{l}\text { S1 PT XYZ sells quality products } \\
\text { S2 PT XYZ provides free shipping } \\
\text { discounts throughout Indonesia } \\
\text { S3 Human resources at PT XYZ are } \\
\text { competent } \\
\text { S4 PT XYZ always delivers on time } \\
\text { S5 PT XYZ has responsible services } \\
\text { to customers }\end{array}$ & $\begin{array}{l}\text { W1 The management at PT XYZ is } \\
\text { not well organized } \\
\text { W2 The technology at PT XYZ is } \\
\text { still quite simple } \\
\text { W3 Customers are difficult to find } \\
\text { channels at PT XYZ } \\
\text { W4 Human resources productivity at } \\
\text { PT XYZ is still low } \\
\text { W5 Standard Operating Procedures } \\
\text { at PT XYZ are less efficient }\end{array}$ \\
\hline Opportunity & SO Strategy & WO Strategy \\
\hline
\end{tabular}

www.scirj.org

(C) 2020, Scientific Research Journal

http://dx.doi.org/10.31364/SCIRJ/v8.i12.2020.P1220827

This publication is licensed under Creative Commons Attribution CC BY. 
O1 PT XYZ has the largest market in Indonesia O2 PT XYZ has a strong brand O3 Utilization of Information Technology can increase efficiency in general

O4 PT XYZ often has recurring income

O5 There is a cooperation agreement between PT XYZ and customers

\begin{tabular}{|l|}
\hline Threats \\
T1 Competitors threaten to offer a \\
better price or value
\end{tabular}
T2 PT XYZ's margins are threatened by competitors or technology

T3 There is smuggling of goods from external parties

T4 There are customer relationships that are in danger of deteriorating T5 PT XYZ is late in adopting technology
SO1 PT XYZ can expand the market share (S1, S2, S3, S4, S5, O1, O2, O3, O4, O5)

SO2 PT XYZ can improve product quality $(\mathrm{S} 1, \mathrm{O} 1)$

SO3 PT XYZ collaborates with importers (S, S4, S5, O4, O5)

\section{ST Strategy}

ST1 Maintain price stability so that it remains affordable by customers (S2, S5, T2, T4)

ST2 Maintain good relations with customers (S1, S2, S4, S5, T3, T4, T5)

ST3 Improve service to retain customers (S2, S4, S5, T1, T2, T4)
WO1 The use of technology such as creating a special website to develop channels (W2, W3, O1, O2, O3)

WO2 improve the company's internal management (W1, W4, O3)

WO3 Improve the company's Standard Operational Procedure (SOP)

\section{WT Strategy}

WT1 Take advantage of technology to increase productivity of Human Resources (W1,W2,W4,W5,T5)

WT2 Improve channels to keep customers from moving (W2,W3,T2,T4)

WT3 Cooperating with delivery couriers (W2, W4, W5, T1, T2)

\section{Determination of Alternative Strategies}

The process of determining alternative strategies uses the Analytical Hierarchy Process (AHP) method which aims to determine the priority between the strategies obtained from the results of the SWOT matrix analysis by filling out a questionnaire by 3 persons of expert who are in direct contact with business process retail equipment of E-KTP products at PT XYZ.

Decomposition is the arrangement of the hierarchical structure of AHP. The hierarchical structure explain that the choice alternatives into 3 levels. Level 1 (objective) is the strategic priority of SWOT. Level 2 is a criterion consisting of SO, WO, St and WT. While level 3 is the sub-criteria consisting of SO1, SO2, WO1, WO2, WO3, ST1, ST2, WT1, and WT2 as shown in the Figure 6.

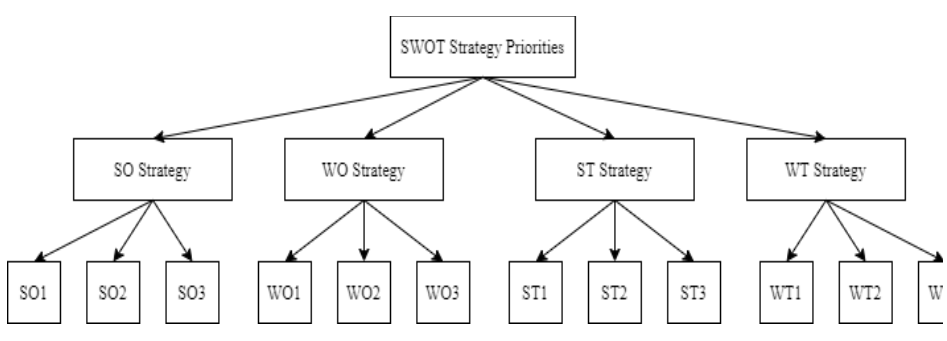

Figure 6 Hierarchial Structure

The calculation of alternative strategies is done by calculating priority criteria, calculating priority vector, calculating consistency and calculating CR. Table 19 is a table that shows the calculation results of each alternative strategy

Table 19 Calculation of Alternative Strategy

\begin{tabular}{|c|c|c|c|c|c|}
\hline $\begin{array}{l}\text { Criteri } \\
\text { a }\end{array}$ & $\begin{array}{l}\text { Priorit } \\
\text { y } \\
\text { Criteri } \\
\text { a }\end{array}$ & $\begin{array}{l}\text { Alternative } \\
\text { strategies }\end{array}$ & $\begin{array}{l}\text { Priorit } \\
\mathrm{y} \\
\text { Vector }\end{array}$ & $\begin{array}{l}\text { Consistenc } \\
\text { y }\end{array}$ & CR \\
\hline \multirow[t]{3}{*}{ SO } & \multirow[t]{3}{*}{0,32} & $\begin{array}{ll}\text { SO1 } & \text { PT } \\
\text { XYZ } & \text { can } \\
\text { expand } & \text { the } \\
\text { market } & \\
\text { share } & \\
\end{array}$ & 0,33 & 3,98 & \multirow[t]{3}{*}{$\begin{array}{l}0,0 \\
5\end{array}$} \\
\hline & & $\begin{array}{l}\text { SO2 PT } \\
\text { XYZ can } \\
\text { improve } \\
\text { product } \\
\text { quality }\end{array}$ & 0,41 & 3,11 & \\
\hline & & $\begin{array}{l}\text { SO3 PT } \\
\text { XYZ } \\
\text { collaborate } \\
\text { s with } \\
\text { importers }\end{array}$ & 0,26 & 2,08 & \\
\hline WO & 3,77 & $\begin{array}{l}\text { WO1 The } \\
\text { use of } \\
\text { technology } \\
\text { such as } \\
\text { creating a } \\
\text { special }\end{array}$ & 0,32 & 3,23 & $\begin{array}{l}0,0 \\
8\end{array}$ \\
\hline
\end{tabular}

www.scirj.org

(C) 2020, Scientific Research Journal

http://dx.doi.org/10.31364/SCIRJ/v8.i12.2020.P1220827

This publication is licensed under Creative Commons Attribution CC BY. 


\begin{tabular}{|l|l|l|l|l|l|}
\hline & $\begin{array}{l}\text { website to } \\
\text { develop } \\
\text { channels }\end{array}$ & & & \\
\hline & $\begin{array}{l}\text { WO2 } \\
\text { Improve } \\
\text { the } \\
\text { company's } \\
\text { internal } \\
\text { manageme } \\
\text { nt }\end{array}$ & 0,29 & 3,07 & \\
\hline & $\begin{array}{l}\text { WO3 } \\
\text { Improve } \\
\text { the } \\
\text { company's }\end{array}$ & 0,38 & 2,99 & \\
Standard \\
Operational \\
ST
\end{tabular}

\begin{tabular}{|l|l|l|l|}
\hline & $\begin{array}{l}\text { to increase } \\
\text { productivit } \\
\text { y of Human } \\
\text { Resources }\end{array}$ & & \\
\hline & $\begin{array}{l}\text { WT2 } \\
\text { Improve } \\
\text { channels to } \\
\text { keep } \\
\text { customers } \\
\text { from } \\
\text { moving }\end{array}$ & 0,35 & 3,43 \\
\hline & $\begin{array}{l}\text { WT3 } \\
\text { Cooperatin } \\
\text { g with } \\
\text { delivery } \\
\text { couriers }\end{array}$ & 0,27 & 2,63 \\
\hline
\end{tabular}

Based on the result of AHP data processing, it can we seen that the priority criteria from the highest to the lowest are WO, SO, WT, and ST, so that the priority order of alternative strategies for selling the equipment of E-KTP products at PT $\mathrm{XYZ}$ is as follows :

WO1 The use of technology such as creating a special website to develop channels

WO2 Improve the company's internal management

WO3 Improve the company's Standard Operational Procedure (SOP)

SO2 PT XYZ can improve product quality

SO1 PT XYZ can expand the market share

SO3 PT XYZ collaborates with importers

WT2 Improve channels to keep customers from moving

WT1 Take advantage of technology to increase productivity of Human Resources

WT3 Cooperating with delivery couriers

ST3 Improve service to retain customers

ST1 Maintain price stability so that it remains affordable by customers

ST2 Maintain good relations with customers

\section{The Proposed of Business Model Canvas}

www.scirj.org

(C) 2020, Scientific Research Journal 


\begin{tabular}{|c|c|c|c|c|c|}
\hline \multirow[t]{2}{*}{$\begin{array}{l}\text { Key } \\
\text { Partners } \\
\text { - Supplier of the } \\
\text { Equipment of E- } \\
\text { KTP } \\
\text { - Reseller of the } \\
\text { Equipment of E- } \\
\text { KTP } \\
\text { - CourierDelivery of } \\
\text { Goods }\end{array}$} & $\begin{array}{l}\text { Key } \\
\text { Activities } \\
\text { - Sales of the } \\
\text { Equipment of E- } \\
\text { KTP Poducts } \\
\text { - Maintain Product } \\
\text { Quality } \\
\text { - Improve Internal } \\
\text { Management } \\
\text { - Improve SOP } \\
\text { - Create a Website }\end{array}$ & \multirow{2}{*}{\multicolumn{2}{|c|}{$\begin{array}{l}\text { Value } \\
\text { Proposition } \\
\text { - Free Shipping } \\
\text { Throughout } \\
\text { Indonesia } \\
\text { - Selling Quality } \\
\text { Products } \\
\text { - Affordable Produt } \\
\text { Prices }\end{array}$}} & $\begin{array}{l}\text { Customer } \\
\text { Relationships } \\
\text { - Walk-in at } \\
\text { the Office } \\
\text { - Phone-in via } \\
\text { 022-5202682 } \\
\text { - Website } \\
\text { - Website } \\
\text { Features for } \\
\text { Complains }\end{array}$ & \multirow[t]{2}{*}{$\begin{array}{l}\text { Customer } \\
\text { Segments } \\
\text { Resellers who } \\
\text { provide the } \\
\text { equipment of e-KIP } \\
\text { products to local } \\
\text { governments } \\
\text { throughout } \\
\text { Indonesia }\end{array}$} \\
\hline & $\begin{array}{l}\text { Key } \\
\text { Resources } \\
\text { - Bvildings } \\
\text { - Office Facilities } \\
\text { - Human Resources } \\
\text { - Financial } \\
\text { - Website Development } \\
\text { Sevices } \\
\text { - Courier Delivery }\end{array}$ & & & $\begin{array}{l}\text { Channels } \\
\text { - Roadshow with } \\
\text { Reseller } \\
\text { - Gathering with } \\
\text { Reseller } \\
\text { - Cooperation } \\
\text { Agreement }\end{array}$ & \\
\hline \multicolumn{3}{|c|}{$\begin{array}{l}\text { Cost } \\
\text { Structure } \\
\text { - Employee Salary } \\
\text { - Shippig Cost } \\
\text { - Marketing Costs } \\
\text { - WebsiteDevelopment Services Fees } \\
\text { - Product DvelopmentCosts }\end{array}$} & \multicolumn{3}{|l|}{$\begin{array}{l}\text { Revenue } \\
\text { Streams }\end{array}$} \\
\hline
\end{tabular}

Figure 7 The Proposed of Business Model Canvas

\section{a. Proposed Customer Segment}

The customer segment of PT XYZ is all resellers of the equipment of E-KTP products throughout Indonesia. Resellers from PT XYZ consist of catalog reseller and e-catalog resellers.

\section{b. Proposed Value Proposition}

PT XYZ currently has a fairly good value proposition in offering price and product quality. Based on the result of the questionnaire, it shows that quality and price are the main attractions of respondents in deciding to buy products at PT XYZ. For this reason, PT XYZ must maintain the quality of the products offered and also maintain the stability of price.

\section{c. Channels Proposed}

To expand the customer segment and to make it easier for customers to find channels from PT XYZ, the company should create a special website to carry out the product order process so from the order process until the delivery process can be monitored by the customer and also by PT XYZ. It is hoped that with a special website, the entire sequence in the process can be carried out transparently.

\section{d. Customer Relationship Proposed}

To build a good relationship with the customers, PT XYZ should provide a platform for customers to submit complaints. As stated in the background, in 2017 the percentage of unread customer's complain emails was $84 \%$, in 2018 it was 92\%, while in 2019 it was $96 \%$. By creating a website, PT XYZ can also add special features as a place for customers to submit complaints. In addition, PT XYZ must maintain customer relations by regularly conducting roadshows with resellers and also holding regular gatherings with resellers.

\section{e. Revenue Streams Proposed}

The revenue generated by $\mathrm{PT} X Y Z$ in retail of the equipment of E-KTP is the result of sales of E-KTP equipment products, namely sales of printers, film ribbons, cleaning kit, smart cards, contact java cards, magical printer and magic card ribbons. The margin from PT XYZ is very dependent on the sales of products, therefore it is very important for PT XYZ to maintain its customers so that the income margin is not disturbed. Based on the results of the questionnaire, it can be seen that the income from one transaction can be replaced by recurring income. For this reason, the cooperation agreement between PT XYZ and resellers is very important to maintain because recurring income can continue to occur in order to maintain the stability of the company's income margin.

\section{f. Key Activities Proposed}

By reviewing the development of a value proposition, precisely in terms of quality, the development of key activities can be carried out by improving product quality, improving internal management and improving Standard Operating Procedure (SOP) to improve product quality. Meanwhile, by reviewing the development of customer relationships and channels, it is necessary to create a website to place orders and create features that are used as a forum for channeling customer complaints.

www.scirj.org

(C) 2020, Scientific Research Journal

http://dx.doi.org/10.31364/SCIRJ/v8.i12.2020.P1220827

This publication is licensed under Creative Commons Attribution CC BY. 


\section{g. Key Resources Proposed}

Human resources is the most important asset of the company. Based on the results of the questionnaire, it is necessary to improve internal management to increase human resource productivity at PT XYZ. As previously explained, PT XYZ has just implemented SAP in company, therefore it is necessary to conduct training for HR to increase knowledge of these HR so that SAP can be carried out optimally.

\section{h. Key Partnership Proposed}

Free shipping throughout Indonesia is a hallmark of PT XYZ. There are many customers who are interested or subscribed to PT XYZ because of this service. However, to maintain the revenue streams from the company, PT XYZ should collaborate with delivery couriers. The process of sending products is carried out every day and in large quantities, so by collaborating with delivery couriers, of course PT XYZ can get lower prices and the courier also benefits. In addition, PT $\mathrm{XYZ}$ still has to maintain relationships with importers so that they always get quality products.

\section{i. Cost Structure}

The costs incurred by PT XYZ are product stock costs, shipping costs, direct labor costs, variable overhead costs. However, monitoring of the eight elements above will ensure that the cost structure will be carried out after the website creation.

\section{CONCLUSION AND SUGGESTION}

\section{Conclusion}

The results of calculations on internal factors and external factors show the way PT XYZ is currently in cell V in the IE matrix with IFE value of 2.32 and an EFE of 2.26. Cell V is referred to as a defense and maintenance strategy which indicates that at this ranking PT XYZ is advised to carry out a market penetration strategy and product development. The SWOT Analysis resulted in 12 strategies with the priority of the strategy being to create a special web to develop a channel with a priority vector of 0.32 . The proposed improvement priority is used to improve business processes and can be done by applying the BMC concept that has been proposed.

\section{Suggestion}

Based on the conclusions and the results of the analysis that has been carried out, the suggestions that might be useful as input and consideration are as follows :

\section{Suggestions for PT XYZ}

PT XYZ can implement the strategy from the research results as a new business model. The proposed business model is expected to have a positive impact on internal and external companies.

\section{Suggestion for Further Research}

The researchers can do research with the same problem but modify the SWOT method with decision-making methods other than AHP such as ANP, Delphi, Topsis or others that involve more interest leaders such as distributors.

\section{REFERENCE}

David, F. R. (2009). Manajemen Strategis Konsep, Buku 1. Jakarta: Salemba Empat.

Dyson, R. (2004). Strategic Development and SWOT Analysis at the University of Warwick.

Hunger, J. D., \& Wheelen, T. L. (2012). Strategic Management and Business Policy : Toward Global Sustainability (13th Edition). New York: Pearson.

Kotler, \& Keller. (2007). Manajemen Pemasaran, Jilid I, Edisi Kedua Belas. Jakarta: PT Indeks.

Osterwalder, A., \& Pigneur, Y. (2012). Business Model Generation. Jakarta: Elex Media Komputindo.

Rangkuti, F. (2014). Analisis SWOT : Teknik Membedah Kasus Bisnis. Jakarta: PT Gramedia Pustaka Utama.

Saaty, T. L. (2008). Decision Making With Analytical Hierarchy Process.

www.scirj.org

(C) 2020, Scientific Research Journal

http://dx.doi.org/10.31364/SCIRJ/v8.i12.2020.P1220827

This publication is licensed under Creative Commons Attribution CC BY. 